\title{
Constraints Perceived by the Farmers in Adoption of Improved Ginger Production Technology- a Study of Low Hills of Himachal Pradesh
}

\author{
Sanjeev Kumar ${ }^{*}$, S. P. Singh ${ }^{2}$ and Raj Rani Sharma ${ }^{3}$
}

${ }^{1,3}$ Dept. of Social Sciences, Dr. YS Parmar University of Horticulture \& Forestry, Nauni, Solan, Himachal Pradesh (173 230), India
${ }^{2}$ Division of Agricultural Economics and ABM, SKUAST- J, Main Campus, Chatha, Jammu, Jammu \& Kashmir (180 009), India

\section{Corresponding Author}

Sanjeev Kumar

e-mail: sharmask93@rediffmail.com

\author{
Article History \\ Article ID: AR1911 \\ Received in $04^{\text {th }}$ October, 2018 \\ Received in revised form $19^{\text {th }}$ December, 2018 \\ Accepted in final form $26^{\text {th }}$ December, 2018
}

\begin{abstract}
The present study was conducted using multistage sampling technique in Jhandutta and Sadar blocks of Bilaspur district of Himachal Pradesh during 2016-17. A sample of 100 ginger growing farmers was collected by personal interview method through well-structured pre tested schedule. The results of the study revealed that in case of technological constraints major constraints faced by the farmers were lack of knowledge about high yielding varieties and lack of technical guidance with mean percent score (MPS) of 89 and 87. The major input supply constraints were worked out to be non-availability of improved high yielding varieties (MPS 84) and lack of processing facilities (MPS 82). Among the economic \& marketing constraints, high fluctuations in market price (MPS 89) and high cost of inputs (MPS 84) were major constraints and in general constraints category, lack of resources followed by low risk bearing abilities of farmers were major constraints with MPS of 78 and 70, respectively. Overall, among all the major categories of constraints, technological constraints (MPS 77.86) were up to greatest extent followed by economic and marketing constraints (MPS 76.75), input supply constraints (MPS 75.00) and general constraints (MPS 59.67), which indicated the need of strengthening the research-extension farmer linkage, provision of cheap credit facilities, establishment of processing units as well as organized regulated markets for efficient production and marketing of ginger crop in the study area.
\end{abstract}

Keywords: Constraints, ginger, mean percent score, schedule

\section{Introduction}

India is known as the "spice bowl of the World" for its superior export quality production of spices. Due to the diverse agroclimatic conditions, almost all the spices are grown splendidly in India. The country has highest number of spices varieties in the World (Bhat et al., 2012; Rajashekar and Kumar, 2017). India is not only the largest producer but also the largest consumer of spices in the World. There has been a steady increase in the area and production of spices in the country over the years. In the year 2016-17, the production of spices in India has reached a level of $8.6 \mathrm{mt}$ from an area of about 4.03 mha (Anonymous, 2018). India is also the largest exporter of spices in the World. In the last five years, Indian spices exports have registered substantial growth in volume and value. During 2017-18, a total of $10,28,060 \mathrm{t}$ of spices and spice products valued INR 17929.55 crores has been exported from the country as against 9,47,790 t valued INR 17664.61 crores in 2016-17 registering an increase of $8 \%$ in volume and $1 \%$ in rupee terms (Anonymous, 2018).

Ginger (Zingiber officinale Roscoe) is one of the major cash crops supporting the livelihood and improving the economic level of many ginger growers in the country. The term 'ginger' was originated from the Sanskrit word 'Sringavera', which means horn-shaped (Ravindran and Babu, 2004). It belongs to Zingiberaceae family and is indigenous to south-eastern Asia (Bijaya, 2018). It is extensively cultivated in India, China, Africa, Jamaica, Mexico and Hawaii (Singh et al., 2008). It is a plant that is used in folk medicine from south-east Asia, Africa, China, India and Jamaica (Sekiwa et al., 2000). Presently, ginger is cultivated throughout the humid tropics. India is the largest producer of the ginger in the world which accounts for $65 \%$ of the world's production of ginger (Sonwani et al., 2018). In 2016-17, the production of ginger in the country was $1.05 \mathrm{mt}$ from an area of about 0.16 mha (Anonymous, 2017). Ginger is being used in different products and is cultivated for both fresh vegetable and as a dried spice in India. It is one of the mainstay in Indian spice account and has been used for flavoring purposes in many products. It is grown for its pungently aromatic underground stem which is an important export crop valued for its powder, oil and oleoresin, all of which have food and medicinal value (Singh et al., 2008; 
Eze and Agbo, 2011). Apart from having tangy flavour, it has appreciable quantities of proteins $(2.3 \%)$,carbohydrates $(12 \%)$, fats $(1 \%)$, minerals $(1.2 \%)$, fibre $(2.5 \%)$ and moisture (81\%) of fresh rhizome (Naresh et al., 2013).The major ginger producing states in the country are Kerala, Karnataka, Sikkim, Meghalaya, Himachal Pradesh, Gujarat, Orissa, West Bengal, Uttaranchal, Assam, Arunachal Pradesh, Mizoram and other North Eastern states (Bheemudada and Natikar, 2016; Meenu and Kaushal, 2017).

In Himachal Pradesh, ginger is mostly grown as a cash crop in mid and low hills of the state. The production of ginger in the state during 2016-17 was 15.30 thousand tonnes from an area of 2.30 thousand ha with productivity of about $6.65 \mathrm{t}$ $\mathrm{ha}^{-1}$ (Anonymous, 2017). It is intensively cultivated in Sirmour, Solan, Mandi, Shimla, Kangra, Bilaspur, Hamirpur and Chamba districts and most of the fresh ginger produced in the state is sold to the nearby states like Punjab, Haryana, Delhi, Uttar Pradesh etc. (Singh and Dhillon, 2015). It is one of the most important cash crops for the farmers of the state fetching remunerative returns (Sharma et al., 2017). Ginger cultivation is both labour and capital intensive and besides, being a long duration crop taking about 6-9 months in midhills from sowing to harvesting. The climatic conditions of mid and low hills of the state are most suitable for cultivation of ginger in the state. However, during the last few years, the crop has been severely damaged by different diseases in field, storage and market (Sharma et al., 2017). Post-harvest losses in ginger is a serious concern in the state as the precious harvest is lost due to negligence in crop production and storage in underground pits and open heaps at various stages. Keeping these facts in view, the present study was conducted to find out the constraints of ginger production under low hills of Himachal Pradesh.

\section{Materials and Methods}

The present study was conducted during agricultural year 2016-17 in the month of October and November in Bilaspur district of Himachal Pradesh, India which falls under SubMontane and Low Hills Subtropical zone (Zone-I) of the state. It is located at $31.34^{\circ} \mathrm{N}$ and $76.69^{\circ} \mathrm{E}$ with an average elevation of 673 amsl. Multistage sampling technique was used to collect the ultimate sample (Erick et al., 2015). At the first stage of sampling, Jhandutta and Sadar blocks of the district were selected purposively as these two blocks are having maximum number of ginger growers in the district and have great potential of increasing production and productivity under the crop. At the second stage of sampling, five villages from each block were selected randomly. At the third stage of sampling, 10 farmers from each village were selected randomly to constitute a sample size of 100 farmers in total. Data were collected by personal interview method through well-structured pre tested schedule. Thereafter, data were tabulated, analyzed and conclusions were drawn keeping in view the objective of the study. Individual aspect- wise constraints of ginger growers were worked out. These were categorized into four categories namely technological constraints, input supply constraints, economic \& marketing constraints and general constraints. Total score obtained for each statement/constraint was calculated. The following statistical methods were used in the present study:

\subsection{Growth rate analysis}

The Compound Annual Growth Rate (CAGR) in area, production and productivity of ginger was estimated by using the exponential growth function of the following form; $\mathrm{Y}=\mathrm{a} \mathrm{b}^{\mathrm{t}}$. $\mathrm{e}_{\mathrm{t}}$ Where, $\mathrm{Y}$ is dependent variable (area/production/productivity), $\mathrm{t}$ is time variable, $\mathrm{e}_{\mathrm{t}}$ is error term and $\mathrm{a}$ and $\mathrm{b}$ are the unknown constants to be estimated.

The above model in the logarithmic form is expressed as; $\log Y=\log a+t \log b$.

Log $a$ and Log $b$ values were obtained using the methods of ordinary least squares and per cent CAGR was computed using the following relationship;

$\%$ CAGR=(Antilog of $(\log b)-1) \times 100$.

Student ' $\mathrm{t}$ ' test was used to test the significance of growth rate.

\subsection{Co-efficient of variation (CV)}

It is a standardized measure of dispersion of a probability distribution or frequency distribution. It is often expressed as a percentage, and is defined as the ratio of the standard deviation to the mean (average). It is a measure of relative variability. It was calculated by using following formula;

$\mathrm{CV}=($ Standard deviation/Mean $) \times 100$

\subsection{Mean percent score}

It was calculated by multiplying total obtained score of the respondents with 100 and divided by the maximum obtainable score.

Mean percent score $=($ Total score obtained $/$ Maximum obtainable score) $\times 100$.

\subsection{Rank}

Ranks were assigned in the descending order according to the mean per cent score obtained to find out the constraints severity in order of priority.

In addition to above statistical methods, descriptive statistics measures such as mean, standard deviation and coefficient of determination $\left(R^{2}\right)$ were also used.

\section{Results and Discussion}

\subsection{Compound annual growth rate in area, production and productivity of ginger in India}

The data related to area, production and productivity of ginger in India have been presented in Table 1 which revealed that the average area, production and productivity under ginger in India during 2001-02 to 2016-17 was found to be 129.37 thousand ha, 589.66 thousand tonne and $4.49 \mathrm{t}$ 
Table 1: Growth rate in area, production and productivity of ginger in India

\begin{tabular}{lccc}
\hline Years & $\begin{array}{c}\text { Area } \\
\text { ('000 ha) }\end{array}$ & $\begin{array}{c}\text { Production } \\
\text { ('000 t) }\end{array}$ & $\begin{array}{c}\text { Productivity } \\
\left(\mathrm{t} \mathrm{ha}^{-1}\right)\end{array}$ \\
\hline $2001-02$ & 84.60 & 317.90 & 3.76 \\
$2002-03$ & 85.90 & 307.40 & 3.58 \\
$2003-04$ & 85.10 & 301.90 & 3.55 \\
$2004-05$ & 95.30 & 359.00 & 3.77 \\
$2005-06$ & 110.60 & 391.20 & 3.54 \\
$2006-07$ & 106.10 & 393.40 & 3.71 \\
$2007-08$ & 104.10 & 382.60 & 3.68 \\
$2008-09$ & 143.90 & 610.40 & 4.24 \\
$2009-10$ & 142.10 & 679.30 & 4.78 \\
$2010-11$ & 167.40 & 702.00 & 4.19 \\
$2011-12$ & 155.10 & 755.60 & 4.87 \\
$2012-13$ & 136.30 & 682.60 & 5.01 \\
$2013-14$ & 138.20 & 683.16 & 4.94 \\
$2014-15$ & 153.10 & 795.82 & 5.20 \\
$2015-16$ & 156.91 & 1025.11 & 6.53 \\
$2016-17$ & 160.48 & 1047.19 & 6.53 \\
Mean & 129.37 & 589.66 & 4.49 \\
Standard deviation & 29.80 & 247.35 & 0.99 \\
$R^{2}$ & 0.81 & 0.92 & 0.84 \\
CAGR & $4.3606^{* *}$ & $8.2719^{* *}$ & $3.7478^{* *}$ \\
CV & $(0.0060)$ & $(0.0068)$ & $(0.0046)$ \\
\hline Source: An & 22.10 & 41.94 & 21.98 \\
\hline
\end{tabular}

Source: Anonymous, 2018; Figures in parenthesis indicate standard error; ${ }^{* *}$ : Significant at $p>0.01$

$\mathrm{ha}^{-1}$, respectively. Positive growth rate was found in area, production and productivity with highest growth rate in production with $8.2719 \%$ annum $^{-1}$, followed by area with $4.3606 \%$ annum $^{-1}$ and productivity with $3.7478 \%$ annum ${ }^{-1}$. The growth rate for area, production and productivity were found to be positive and significant at one per cent level of significance. Whereas, with respect to instability index the highest variation was seen in production with $41.94 \%$ followed by area with $22.10 \%$ variation and the variation observed in productivity was $21.98 \%$.

\subsection{Constraints related to adoption of improved ginger production technology}

The constraints under present investigation were considered as major impediments that prohibit the farmers to adopt the improved ginger production technology with in the study area. The results pertaining to various aspect-wise constraints perceived by the farmers have been presented below in subsequent tables.

\subsubsection{Technological constraints}

The data related to technological constraints (Table 2) revealed that among the various technological constraints, lack of knowledge about high yielding varieties was ranked first with MPS 89 followed by lack of technical guidance, lack of knowledge about value addition of ginger, lack of knowledge about insect pest and diseases management, lack of knowledge about fertilizer dosage and method of fertilizer application, lack of technical know- how about curing of rhizomes and lack of knowledge about seed treatment with MPS score of 87, 84, 76, 72, 69 and 68, respectively. From the findings, it is concluded that the main technical constraints for farmers in adoption of improved ginger production technology were lack of knowledge about high yielding varieties and lack of technical guidance. These findings are supported by Vikas et al., 2016.

Table 2: Technological constraints perceived by the ginger growers in the study area

\begin{tabular}{llcc}
\hline SI. No. & Technological constraints & MPS & Rank \\
\hline a) & $\begin{array}{l}\text { Lack of knowledge about high } \\
\text { yielding varieties }\end{array}$ & 89 & I \\
b) $\quad \begin{array}{l}\text { Lack of technical guidance } \\
\text { c) }\end{array}$ & 87 & II \\
& $\begin{array}{l}\text { Lack of knowledge about seed } \\
\text { treatment }\end{array}$ & 68 & VII \\
d) $\quad \begin{array}{l}\text { Lack of knowledge about value } \\
\text { addition of ginger }\end{array}$ & 84 & III \\
e) $\quad \begin{array}{l}\text { Lack of knowledge about fertilizer } \\
\text { dosage and method of fertilizer }\end{array}$ & 72 & V \\
& $\begin{array}{l}\text { application } \\
\text { Lack of technical know- how about }\end{array}$ & 69 & VI \\
f) & & \\
curing of rhizomes & $\begin{array}{l}\text { Lack of knowledge about insect pest } \\
\text { and diseases management }\end{array}$ & 76 & IV \\
& & & \\
\hline
\end{tabular}

\subsubsection{Input supply constraints}

An analysis of data related to input supply constraints (Table 3) revealed that non-availability of improved high yielding varieties of ginger crop with MPS 84 was the major input supply constraints and was ranked first in the study area. Lack of processing facilities in the study area, labour scarcity, inadequate irrigation facilities, high requirement of manure and fertilizers for high yielding varieties and non- availability of fertilizers at peak season were the other input supply constraints in the study area and were ranked II, III, IV, V and VI with MPS of $82,79,72,71$ and 62 , respectively. These findings are in close conformity with the findings of Singh and Dhillon, 2015; Vikas et al., 2016.

\subsubsection{Economic and marketing constraints}

The results related to economic and marketing constraints have been presented in Table 4 which revealed that high 
Table 3: Input supply constraints perceived by the ginger growers in the study area

\begin{tabular}{llcc}
\hline SI. No. & Input supply constraints & MPS & Rank \\
\hline a) & $\begin{array}{l}\text { Non-availability of improved high } \\
\text { yielding varieties of ginger crop }\end{array}$ & 84 & I \\
b) & $\begin{array}{l}\text { High requirement of manure and } \\
\text { fertilizers for high yielding varieties }\end{array}$ & 71 & V \\
c) & $\begin{array}{l}\text { Non- availability of fertilizers at peak } \\
\text { season }\end{array}$ & 62 & VI \\
d) & Labour scarcity & 79 & III \\
e) & Inadequate irrigation facilities & 72 & IV \\
f) & Lack of processing facilities in the & 82 & II \\
& study area & & \\
\hline
\end{tabular}

Table 4: Economic and marketing constraints perceived by the ginger growers in the study area

\begin{tabular}{llll}
\hline SI. No. & Economic and marketing constraints & MPS & Rank \\
\hline a) & Labour intensive crop & 62 & XII \\
b) & High cost of inputs & 84 & II \\
c) & High cost of labour & 76 & VII \\
d) & Lack of credit facilities & 78 & VI \\
e) & High cost of planting material & 67 & XI \\
f) & Poor access to market information & 74 & IX \\
g) & Un-organized marketing & 83 & III \\
h) & Lack of regulated market & 81 & IV \\
i) & High fluctuations in market price & 89 & I \\
j) & High cost of transportation & 72 & X \\
k) & Non receipt of payment in time & 75 & VIII \\
I) & Lack of processing units and co- & 80 & V \\
& operative societies & & \\
\hline
\end{tabular}

fluctuations in market price, high cost of inputs and unorganized marketing were the three major economic \& marketing constraints in the study area. These were ranked I, II and III with MPS of 89, 84 and 83, respectively. Lack of regulated markets, lack of processing units and co-operative societies, lack of credit facilities, high cost of labour, nonreceipt of payment in time and poor access to market information were ranked IV, V, VI, VII, VIII and IX, respectively with respective MPS of $81,80,78$ and 76,75 and 74 . Likewise, high cost of transportation with MPS 72, high cost of planting material with MPS 67 and labour intensive crop with MPS 62 were ranked tenth, eleventh and twelfth, respectively. These findings are supported by Vikas et al., 2016.

\subsubsection{General constraints}

The results in the Table 5 revealed that lack of resources with MPS 78 was ranked first among all general constraints in the
Table 5: General constraints perceived by the ginger growers in the study area

\begin{tabular}{llcc}
\hline Sl. No. & General constraints & MPS & Rank \\
\hline a) & Natural calamities & 32 & VI \\
b) & Low risk bearing abilities of farmers & 70 & II \\
c) & Lack of resources & 78 & I \\
d) & Adverse climatic conditions at the & 48 & V \\
& critical stages of the crop & & \\
e) & Lack of motivating agencies in the & 68 & III \\
& study area & & \\
f) & Weak research-extension farmer & 62 & IV \\
& linkage & & \\
\hline
\end{tabular}

study area followed by low risk bearing abilities of farmers, lack of motivating agencies in the study area, weak researchextension farmer linkage, adverse climatic conditions at the critical stages of the crop and natural calamities which were ranked II, III, IV, V and VI with respective MPS of 70, 68, 62, 48 and 32 . It was concluded that major general constraints for farmers in adoption of improved ginger production technology were lack of resources and low risk bearing abilities of farmers. These findings are supported by Singh \& Dhillon, 2015 and Vikas et al., 2016.

\subsubsection{Overall constraints perceived}

To work out the overall constraints perceived by farmers in adoption of improved ginger technology in the study area, the overall score of each category was pooled and results have been presented in Table 6 . The data presented in the table revealed that among the selected constraints, technological constraints were up to the greatest extent faced by the ginger growers with MPS 77.86 and was ranked first followed by economic and marketing constraints, input supply constraints and general constraints with respective MPS of 76.75, 75.00 and 59.67 and were ranked II, III and IV, respectively. These findings are in the conformity with the findings of Vikas et al., 2016.

Table 6: Overall constraints perceived by the ginger growers in the study area

\begin{tabular}{llcc}
\hline SI. No. & Constraints & MPS & Rank \\
\hline 1 & Technological constraints & 77.86 & I \\
2 & Input supply constraints & 75.00 & III \\
3 & Economic and marketing constraints & 76.75 & II \\
4 & General constraints & 59.67 & IV \\
\hline
\end{tabular}

\section{Conclusion}

In general, the major constraints perceived by the farmers in adoption of improved ginger production technology in the study area were lack of knowledge about high yielding varieties, lack of technical guidance, lack of processing 
facilities, high fluctuations in market price, high cost of inputs and low risk bearing abilities of the farmers. This indicated that there is need of strengthening the research-extension farmer linkage and establishment of regulated markets for efficient production and marketing of ginger.

\section{References}

Anonymous, 2017. Horticultural Statistics at a Glance 2017. Horticulture Statistics Division, Ministry of Agriculture \& Farmer's Welfare, Government of India, New Delhi, 231. Available at http://agricoop.nic.in/statistics/ horticulture.

Anonymous, 2018. Spices Board of India. Ministry of Commerce and Industry, Government of India, New Delhi. Available at http://www.indianspices.com/spicesdevelopment/spice-catalogue.

Bhat, B.S., Murthy, C., Yusuf, M., 2012. Economics of production of ginger in Uttara Kannada district of Karnataka. International Research Journal of Agricultural Economics and Statistics 3(1), 181-185.

Bheemudada, A.B., Natikar, K.V., 2016. A study on knowledge level of farmers about the ginger cultivation practices and constraints in adoption of improved practices. Journal of Farm Sciences 29(1), 133-134.

Bijaya, B.B., 2018. Ginger processing in India (Zingiber officinale): A review. International Journal of Current Microbiology and Applied Sciences 7(4), 1639-1651.

Erick, K.K., Benjamin M.K., Lawrence K.K., Geoffrey K.K., 2015. Determinants of market facilitators choice by smallholder farmers in Laikipia County, Kenya. IOSR Journal of Agriculture and Veterinary Science 8(1), 78-82.

Eze, J.I., Agbo, K.E., 2011.Comparative studies of sun and solar drying of peeled and unpeeled ginger. American Journal of Scientific and Industrial Research. 2(2), 136-143.

Meenu, G., Kaushal, M., 2017. Diseases infecting ginger (Zingiber officinale Roscoe): A review. Agricultural Reviews 38(1), 15-28.
Naresh, B., Srivastava, S.K., Agarwal, S., 2013. Traditional storage practices of spices and condiments in Odisha. Indian Journal of Traditional Knowledge 12 (3), 518-523.

Rajashekar, Kumar, D., 2017. Cost and return of ginger in Bidar district of Karnataka an economic analysis. Journal of Pharmacognosy and Phytochemistry 6(5), 472-475.

Ravindran, P.N., Babu, K.N., 2004. Ginger: The genus Zingiber. CRC Press, Boca Raton, London, New York, Washington D.C., 1.

Sekiwa, Y., Kubota, K., Kobayashi A., 2000. Isolation of novel glycosides from ginger and their antioxidative activity. Journal of Agricultural and Food Chemistry 48(2), 373-377.

Sharma, S., Dohroo, N.P., Veerubommu, S., Phurailatpam, S., Thakur, N., Yadav, A.N., 2017. Integrated disease management of storage rot of ginger (Zingiber officinale) caused by Fusarium sp. in Himachal Pradesh, India. International Journal of Current Microbiology and Applied Sciences 6(12), 3580-3592.

Singh, G., Kapoor. I.P., Singh, P., Heluani, C.S., Lampasona, M.P., Catalan, C.A., 2008. Chemistry, antioxidant and antimicrobial investigations on essential oil and oleoresins of Zingiber officinale. Food and Chemical Toxilogy 46(10), 3295-3302.

Singh, S., Dhillon, S.S., 2015. Socio- economic analysis of ginger crop in Himachal Pradesh. Indian Journal of Hill Farming 28(1), 35-42.

Sonwami, D.K., Koshta, A.K., Tigga, B., 2018. An economic analysis of production and marketing of ginger in Bilaspur district of Chhattisgarh, India. International Journal of Current Microbiology and Applied Sciences 7(1), 2195-2201.

Vikas, K., Sisodia, S.S., Chandra, C.K., Bhavendra T., 2016. Constraints perceived by the farmers in adoption of improved ginger production technology in Udaipur district of Rajasthan. International Journal of Agriculture Sciences 8(57), 3154-3157. 